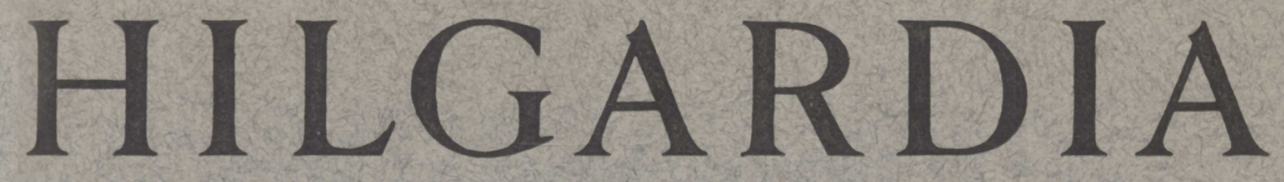

A Journal of Agricultural Science Published by the California Agricultural Experiment Station

CONTENTS

CYSTEINE AND RELATED COMPOUNDS FOR DIFFERENTIATING MEMBERS OF THE GENUS SALMONELLA

W. R. HINSHAW

\title{
MICROANATOMY OF THE DUODENUM \\ OF THE TURKEY
}

LAUREN E. ROSENBERG

This Issue Completes Volume 13

UNIVERSITY OF CALIFORNIA · BERKELEY, CALIFORNIA 
MICROANATOMY OF THE DUODENUM OF THE TURKEY

LAUREN E. ROSENBERG 



\section{MICROANATOMY OF THE DUODENUM OF THE TURKEY ${ }^{1}$}

LAUREN E. ROSENBERG ${ }^{2}$

\section{INTRODUCTION}

The PATHOLOGist or physiologist dealing with mammalian subjects may refer to an extensive literature on normal histology when desiring to make comparisons with the phenomena he encounters. Workers in avian pathology or physiology find, on the other hand, that the histology of birds is not well known and that the articles are inconveniently scattered in a variety of journals in several languages. No comprehensive work on the complete normal histology of birds or of a single bird species has ever been published.

Recent attempts to solve problems dealing with intestinal disturbances in flocks of chickens and turkeys have emphasized this inadequacy. 'The present contribution deals with the detailed structure of the duodenum of the domestic turkey, Meleagris gallopavo.

To date, the best work on the histology of the bird intestine appears in eight papers by Clara (1925 to 1927b, inclusive), ${ }^{3}$ constituting a comparative study of representatives of several orders of birds, including the Galliformes, but with nothing specifically on the turkey. Calhoun (1933) discusses the gross histology of the digestive tract of the domestic fowl, Gallus gallus domesticus, but her account is inadequate for the finer details of cell structure.

Though this paper deals mainly with tissues of the adult, it contains a brief section on the conditions obtaining in younger birds. The normal adults used were over eight months of age."

\section{GROSS STRUCTURE}

The duodenum in the turkey is considered to be that part of the small intestine extending from the exit of the gizzard to the entrance of the pancreatic ducts. From the gizzard the duodenum makes a long posterior loop within which are the lobes of the pancreas, the whole being held together by a mesentery.

\footnotetext{
${ }^{1}$ Received for publication May 19, 1939.

${ }^{2}$ Instructor in Zoölogy, and Junior Zoölogist in the Experiment Station.

${ }^{3}$ See "Literature Cited" for complete data on citations, which are referred to in the text by author and date of publication.

4 The turkeys used in this investigation were reared under routine conditions by the Division of Poultry Husbandry and showed no symptoms of disease or malnutrition. Thanks are due to Dr. V.S. A smundson for his coöperation in this matter.
} 


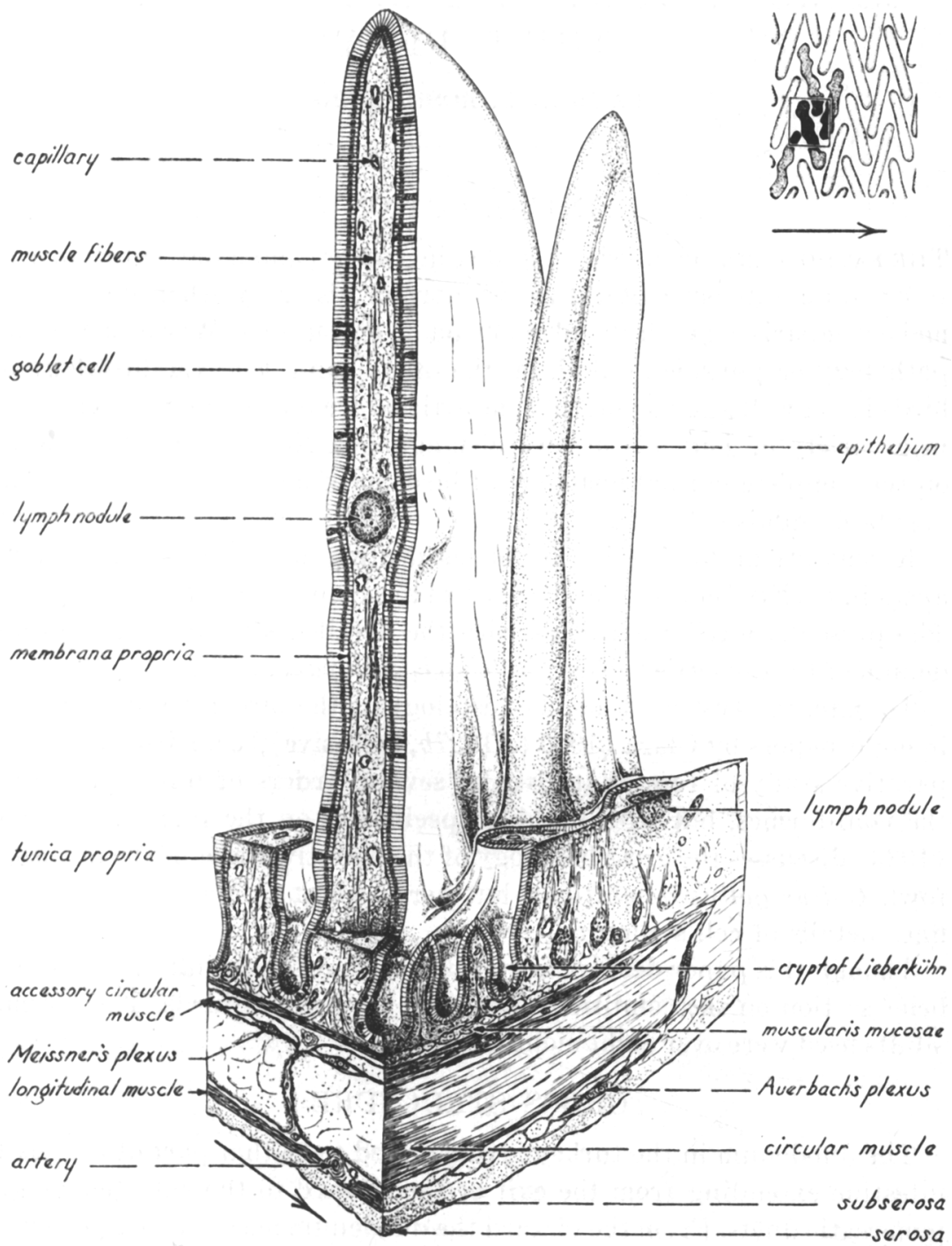

Fig. 1.-Idealized stereogrammatic section of turkey duodenum $\times 40$. (The inset is a surface view of intestine with the blackened villi representing the area from which such a section might be taken.) The arrows indicate the longitudinal axis of the intestine. 
In total length the duodenum varies from 29 to $39 \mathrm{~cm}$; its outside diameter is roughly $10 \mathrm{~mm}$; and the wall is approximately 3.5 to $4 \mathrm{~mm}$ thick.

When opened and washed free of intestinal mucus and debris, the internal surface of the duodenum presents a velvety appearance because of the long, close-set, tonguelike plates, the villi, that cover the entire surface. The villus plates are set in a precise geometric fashion, forming zigzag rows longitudinally and circularly (fig. 1; plate 1).

\section{GENERAL MICROSCOPIC STRUCTURE}

The villi are covered by a typical columnar epithelium continuous with that of the crypts. The Lieberkïhn crypts are simple, unbranched, saclike structures, regularly placed and fairly constant in number. In two consecutive sections of duodenum, each 1 square millimeter in area, the author has counted 132 and 133, respectively. The cores of the villi and all available spaces around the crypts are occupied by the tunica propria, a loosely aggregated bed of connective tissue containing many free cells of various sorts, lymph nodules, blood vessels, and nerve fibers.

Brunner's glands are not present in the duodenum of the turkey. Clara did not mention them in any of the forms he studied. Calhoun (1933) does state that such glands are present in Gallus gallus domesticus for a short distance in the region between the gizzard and duodenum. Although Kaupp (1918) mentions Brunner's glands for $G$. gallus domesticus, his figure shows them above the muscularis mucosae.

In mammals a well-defined submucosa is present between the muscularis mucosae and the muscularis proper. In birds generally, a submucosa is not developed. In portions of the intestine where heavy folds are formed, a temporary submucosal area is indicated. The muscularis of the turkey is made up of three layers of muscles in contrast to mammalian forms, which show but two. The extra, or accessory, layer, lying adjacent to the muscularis mucosae, consists of circular muscle about as thick as the muscularis mucosae. Adjacent to this accessory layer is a second circular layer, comparable in thickness to that of mammals. In the turkey it is nearly twice as thick as the accessory layer and is composed of freely anastomosing bundles of fibers placed a little diagonally. Because of their oblique arrangement, one does not get a clear picture of entire cells in a cross section of the gut. A well-developed layer of longitudinal muscle bundles comprises the outer lamina of the muscularis. In thickness it is about the same as either the muscularis mucosae or the accessory circular layer. All the muscular coats of the intestine vary considerably in thickness, according to the degree of contraction or relaxation of the gut wall. 
Between the muscularis and the serosa proper lies the subserosa, a layer of connective tissue. The serosa is a single-celled layer of peritoneum.

Nerve plexuses comparable to those of mammals are present. In mammals Meissner's plexus is located in the submucosa, and Auerbach's myenteric plexus is located in the muscularis between the longitudinal and circular layers (Maximow and Bloom, 1938). In the turkey, although both plexuses are found, they vary slightly in their position from the manmalian pattern. Both are located in the muscularis. Meissner's

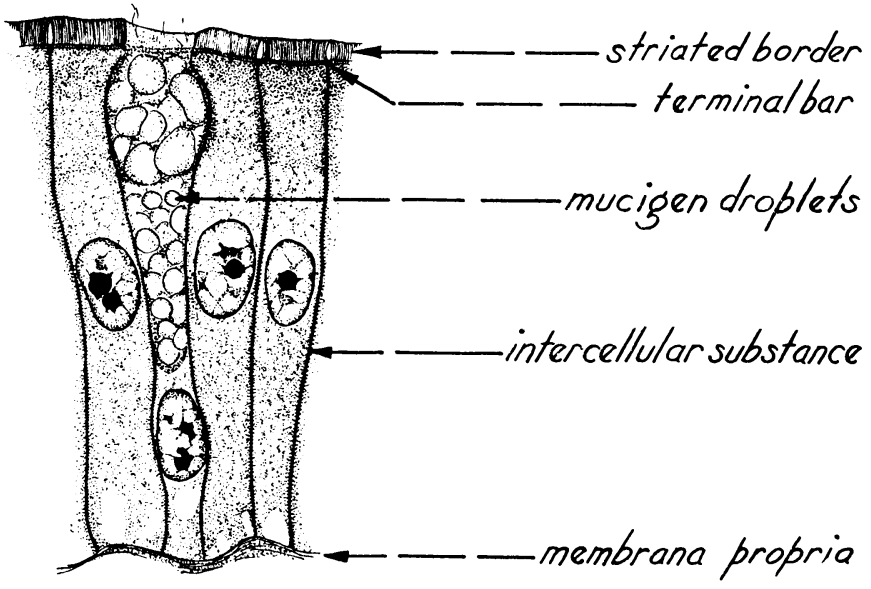

Fig. 2.-Goblet cell of villus epithelium $\times 1280$ (compare plate $3, E)$.

plexus lies between the two layers of circular muscle and is connected by cross branches with Auerbach's plexus, which in the turkey lies in the connective tissue between the muscle bundles of the longitudinal layer.

\section{DETAILED MICROSCOPIC STRUCTURE}

The villi are long lamellae whose surfaces are covered with columnar cells of three types: (1) the chief cells, comprising the greater majority of them; (2) the goblet, or mucous, cells, also numerous; and (3) some basal granular cells.

Chief cells (figs. $1 ; 2 ; 3, A$; plates $3, C, D, E ; 5, D$ ) are simple columnar cells that assume a hexagonal cross section because of the pressure of neighboring cells. In an adult bird they average $54 \mu$ in height and $6 \mu$ in width. The distal, or lumen, end of each is covered with a striated cuticular border. In the distal third of the cell is an oval nucleus containing one or two basophilic nucleoli and considerable dispersed chromatin. Acidophilic nucleoli have not been identified in 
any of the author's material. The cytoplasm is acidophilic with some basophilic granules. On the lumen side of the nucleus there is a lightstaining region proximally and a more basophilic area distally.

The goblet cells (figs. $1 ; 2$; plate $3, D, E$ ) resemble those of mammals. Their nuclei, though slightly smaller than those of the chief cells, are otherwise identical in morphology and staining capacity. The end of the cell toward the lumen does not possess a striated border like that found on chief cells. Goblet cells occur among the chief cells, but only rarely are two found side by side. In a small area the various goblet cells may be in different stages of activity. According to Clara (1926a), goblet cells of birds are extremely active; a second cycle of mucous secretion may be initiated before the first accumulation has been discharged.

Basal granular cells are found on the villi only in small numbers (fig. $3, A$; plate $5, D$ ). At their bases they are about the same in width as the chief cells, but the distal portion of each tapers and disappears near the lumen. The majority of the granules are located proximal to the nucleus and are decidedly basophilic, whereas in mammals they are acidophilic. The nuclei are smaller and more spherical than those of the chief cells. Although basal granular cells are easily demonstrated in turkey tissues by all the ordinary techniques, the most striking results are obtained with Susa-Heidenhain fixation, commonly called "Susa's fixation," followed by Regaud's hematoxylin (see table 1, p. 646).

In the literature the basal granular cells are mentioned under a variety of names, including "gelben" (Schmidt, 1905), "gekörnten" (Clara, 1925), "chromaffinen" and "azidophil" (Kull, 1913), "argentaffin" (Masson, 1928), "Kultschitzky" (Kultschitzky, 1897), and "enterochromaffin" (Ciaccio, 1907).

The cells of the villus epithelium rest upon a basement membrane, the membrana propria (figs. $1 ; 2 ; 3, A$; plate $3, C$ ), which separates the epithelium from the tunica propria. The membrana propria of the villus is continuous with that around the Lieberkühn crypt (figs. 1; $4, A, B ; 6$; plates $5, A, B, C, E ; 6, D)$.

Mitosis has not been observed in any of these three cell types of the villi.

The crypts of Liberkühn (fig. 1) are situated at the bases of the villi, from which they arise singly or in groups. Their epithelium is a continuation of the villus epithelium, and the three cell types of the villus are likewise found in the crypts. The chief cells are shorter (20 to $22 \mu$ in height), with a more basophilic cytoplasm. The striated border becomes less distinct toward the base of the crypt, but the terminal bars remain well developed. The goblet cells, though comparatively more 


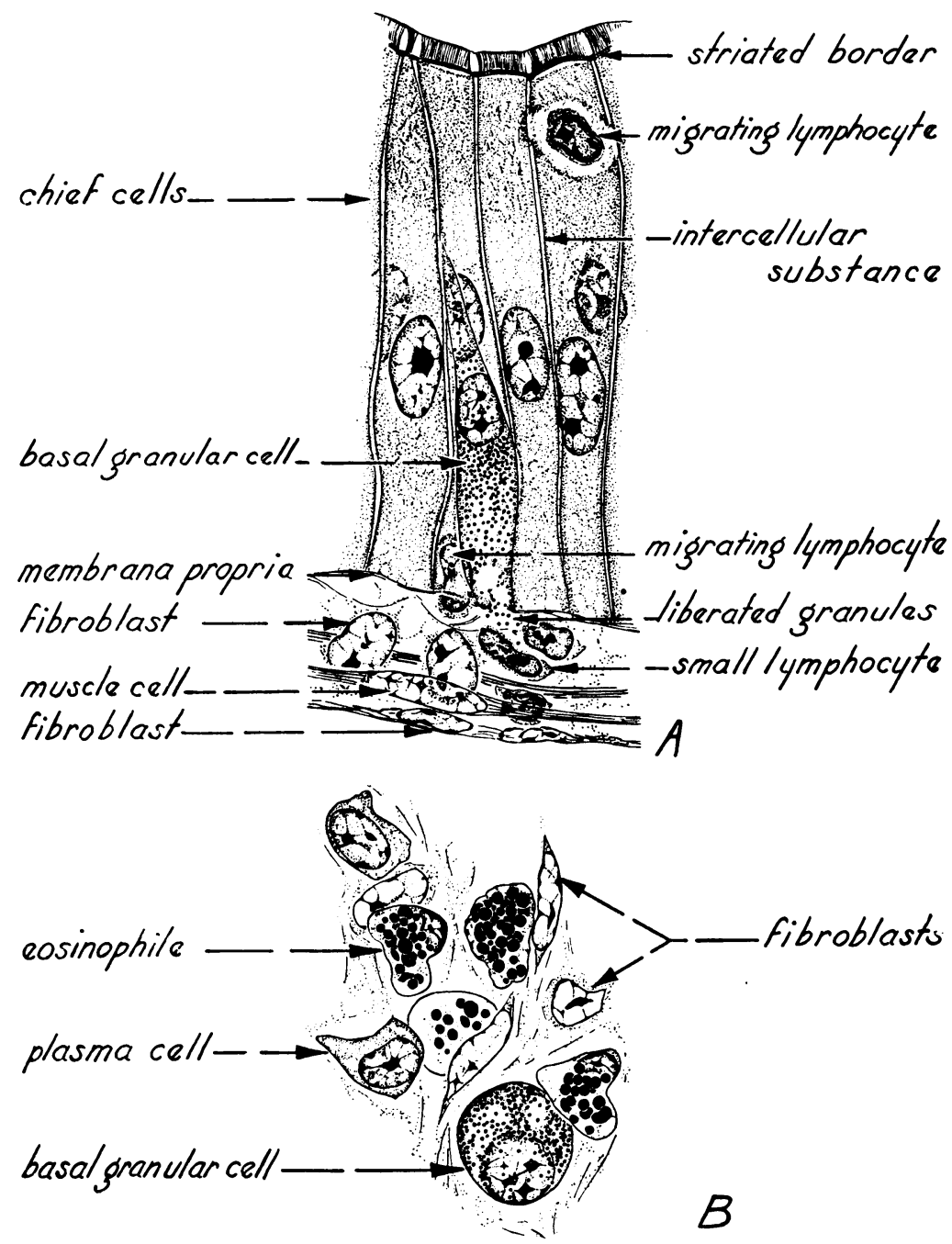

Fig. 3.- $A$, A portion of villus epithelium to show typical chief cells, a basal granular cell, and other neighboring elements $\times 1280$. The basal granular cell is liberating some of its granules into the tunica propria. A lymphocyte is penetrating the membrana propria at the base of this cell (compare plate $5, D$ ). $B, A$ portion of tunica propria from the crypt region to show a free basal granular cell, eosinophiles, and neighboring elements $\times 1280$ (compare plate $\mathbf{5}, \boldsymbol{E})$. 
numerous, are identical in structure with those of the villus mucosa. Basal granular cells are fairly numerous and are located principally in the deepest part of the crypt (fig. $4, A, B$; plate $5, A, B, C$ ), where they assume a more conical shape with the apex of the cone toward the lumen of the crypt. In such cases the distal pole of the cell is too small for a striated border; in fact, it is hard to demonstrate that the apex of the cell really reaches the lumen side of the epithelium. The nuclei are spherical, with well-stained dispersed chromatin and one or two nucleoli. The granules, small and numerous, staining intensely with chromatin stains and often obscuring a part of the nucleus, are mostly massed in the proximal part of the cell with the nucleus just distal to them. The nucleus has been likened to a ball valve (Macklin and Macklin, 1928) serving to hold the granules at the proximal pole of the cell. As shown by Masson (1914) for human beings, the basal granular cells occur singly, and rarely will two be found side by side. Occasionally one sees a few granules on the lumen side of the nucleus. Liberation of the granules into the lumen of the crypt has not previously been observed in any of the vertebrates studied, nor has the fate of the granules ever been determined. Cordier (1921, 1923) considers the basal granular cells to be exocrine in function, comparable with Paneth and pancreatic cells. Kull (1925), Parat (1924), and Masson and Berger (1923) believe them to be endocrine in function. According to Kull and Parat, the secretions of these cells are poured into the blood stream; but Masson calls them "sympaticotropen" glands, believing their products to be secreted into nerve endings in the mucosa.

The present writer has observed several instances, in stained sections, of the liberation of the granules; but in each case a migrating lymphocyte has been found penetrating the membrana propria at one side of the base of the basal granular cell. The liberated granules lie free in the tunica propria. The liberation has been seen in the cells of both the villi and the crypts (figs. $3, A ; 4, A$; plate $5, B, C, D$ ).

Basal granular cells are not confined to the mucosa of the villi and crypts but occasionally occur free in the tunica propria (fig. 3, B; plate $5, E)$. In the latter event they are no longer conical but either spherical or oval, with the granules more evenly distributed instead of being confined to one end of the cell; and the nucleus is spherical and eccentric.

As Masson (1928) has shown, basal granular cells in man may proliferate to cause intestinal cancers, and may also migrate from the crypt into nerve tracts and cause nerve hyperplasias. According to him, all mitosis of these cells occurs in the epithelium of the crypt. The present writer, however, has not encountered recognizable cases of mitosis in these cells in the turkey. 
In man the basal granular cells are found in the intestinal mucosa about the fourth month of fetal life and appear to be derived directly from the cells of the endoderm (Masson, 1928). From observations of
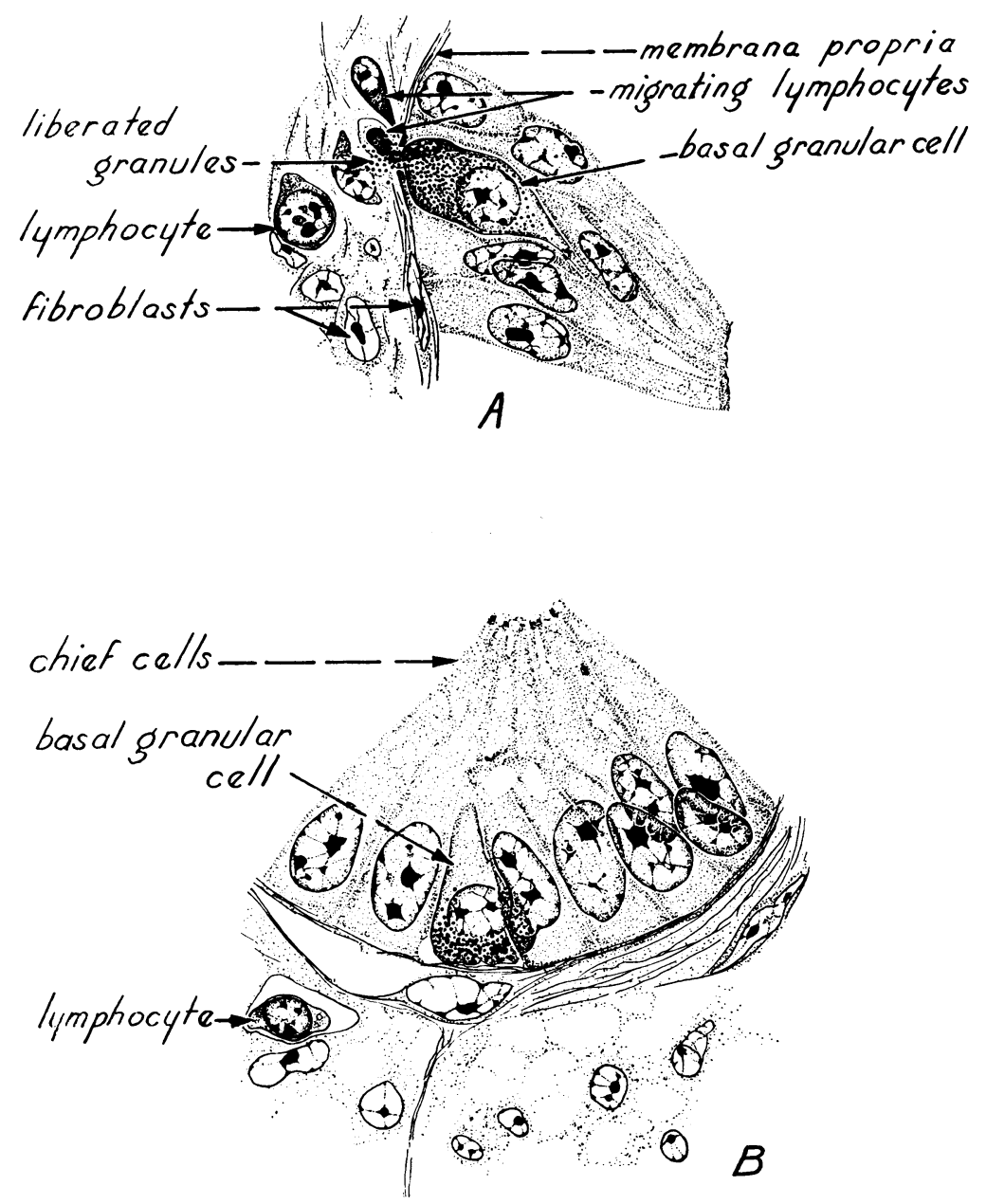

Fig.4.- Sections from the crypts of Lieberkühn $\times 1280$. A, Liberation of granules from a basal granular cell with concurrent migration of a lymphocyte through the membrana propria (compare plate $5, B$ ). $B$, A normal basal granular cell at the base of a crypt (compare plate $5, A)$.

the developing chick embryo, Kull (1913) concluded that they were formed from mesenchymal cells which later invade the epithelium. Simard and Campenhaut (1932), having restudied the development of basal granular cells in the chick, have reached conclusions similar to those of Masson for man. In the chick these cells do arise in the epithelium and 
are thus of endodermal origin. They first appear around 264 hours of incubation, when a few are found at the very end of the anterior intestine, just above the umbilical pedicel. Further differentiations proceed caudally and cranially from this point, and by 336 hours of incubation the cells occur throughout the length of the intestine. By chorioallantoic grafts Simard and Campenhaut were able to show further that basal granular cells will differentiate in the absence of nervous elements. Those in the tunica propria are considered to be migrants from the epithelium. Although this phase of development has not been studied in the turkey, it is probably similar.

Numerous leucocytes are found between the epithelial cells of both the villus and the crypt; some are old lymphocytes which will eventually

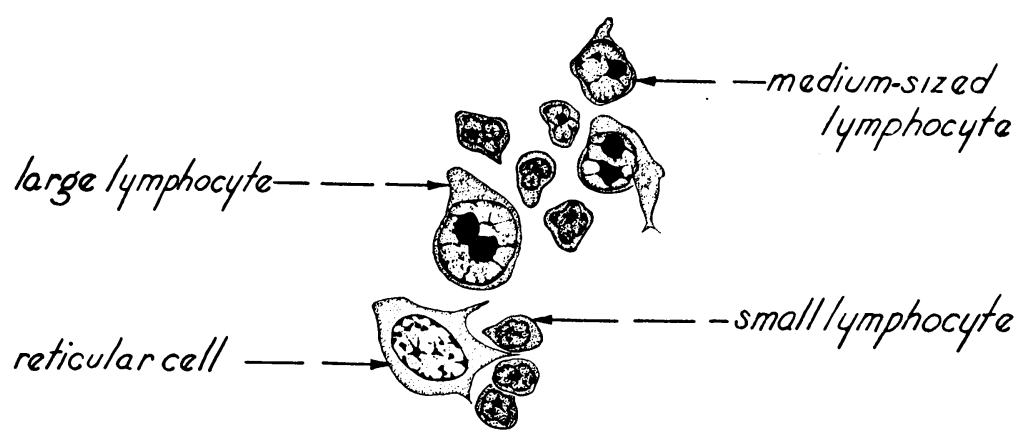

Fig. 5.-A portion of the tunica propria from the villus to show the relative features of the three types of lymphocytes $\times 1280$ (compare plate $7, C$ ).

reach the lumen of the intestine and be destroyed (figs. $3, A ; 4, A$; plates $3, C, D ; 5, B, C, D)$. Others, less numerous, are the "Schollenleukozyten" of Weill (1919) (fig. 6 ; plate 6, $D$ ), of unknown origin; no definite function has been ascribed to them. Weill suggested that they may be secretory; and Keasbey (1923) agrees that they may be cells of external secretion comparable to pepsiniferous cells, although developmental stages are lacking. The schollenleucocytes are generally found in the proximal half of the cell layer and, although never seen to be extruded, are sometimes found near the crypt lumen. In the turkey they are irregular cells of varying sizes with oval to round, darkly staining nuclei. The cytoplasm is clear, with two to ten globules of varying size that are amphophilic after all methods of fixation. After the Susa's fixation, the schollenleucocytes and true eosinophiles appear to be different stages of the same cell, because of their staining affinities and the similarity of their nuclei. Since the granules of the eosinophiles do tend toward basophilic staining, the schollenleucocytes might well represent a phase in 
the degeneration of the true eosinophiles. Since, however, the latter oceasionally migrate through the epithelium without resembling schollenleucocytes, two distinct cell types may be indicated.

The crypt of Lieberkühn is the site of an enormous amount of mitosis from hatching to and throughout mature life (plate 4, $A$ ). As in mammals, mitosis is not found in the cells of the villus epithelium. Since shedding of old cells occurs on the villus, replacement must come from the crypt - a theory first postulated for mammals by Bizzozero (1893). In the turkey the theory is strikingly borne out. The cells rest lightly upon the membrana propria and are evidently capable of movement along

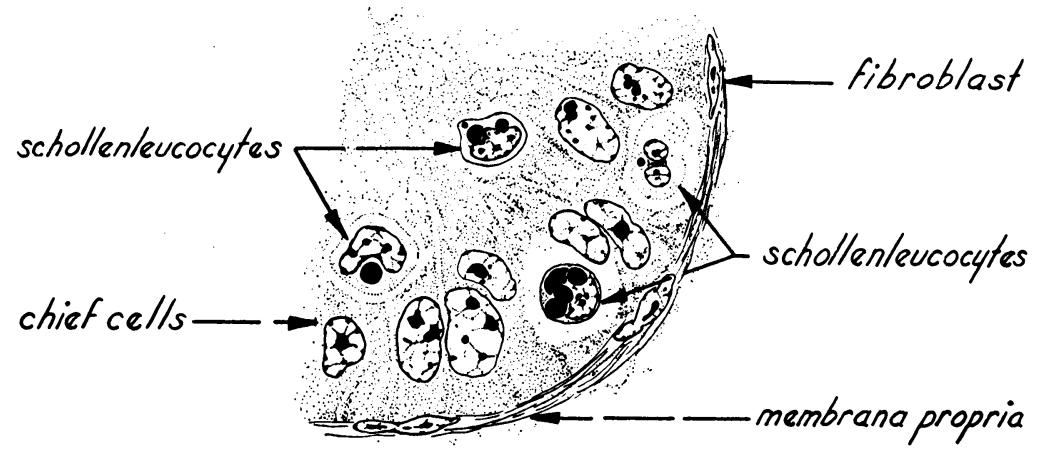

Fig. 6.-Schollenleucocytes in the epithelium of a crypt of Lieberkühn $\times 1280$ (compare plate $6, D$ ).

that membrane from crypt to villus tip. Mitosis in the crypt is far more frequent in the crypts of the duodenum than in the more posterior regions of the intestine. As shown by examinations of various levels of the small intestine, mitoses grow fewer from duodenum to rectum. The theory that crypt cells replace villus epithelium is further borne out by the ease with which the epithelial cells break away from the membrana propria when fixation is not accomplished with sufficient rapidity (Rosenberg, 1940).

Another type of cell often encountered in the Lieberkühn crypts of vertebrates is the Paneth cell, flask-shaped to columnar, with eosinophilic granules in the cytoplasm in the lumen side. This type is not found universally in any group of animals. Although Clara (1926c) describes Paneth cells for the Turdidae and for Anas, he failed to find them in other groups, including the Galliformes. The present writer agrees with this observation, for such cells have not been located in Meleagris by any of several techniques. Tang (1922) postulates a reciprocal relation between basal granular cells and Paneth cells : if one is present in large numbers, the other is lacking. This is the case in turkeys, for basal granu- 
lar cells are numerous in almost any well-fixed $5-\mu$ section. In the bird kingdom, according to Clara (1926c) :

.... das Auftreten von derartigen Körnchenzellen in den Krypten verschiedenen Wirbeltiere ist ein Ausdruck für die weitgehende Differenzierung des Darmepithels, im besonderen des Kryptenepithels, was auch darin sich offenbart, dass bei den Vögeln nur in gut ausgebiedeten Krypten bisher solche Zellen gefunden werden könnten.

As Meleagris has a fairly simple type of Lieberkühn crypt, it would not be expected to possess Paneth cells.

The tunica propria of the adult turkey contains several cell types, and its character varies from the muscularis mucosae to the villus tip. The cores of some villi contain lymph nodules (fig. 1 ; plates $2, B, C ; 7, A, B$ ) whereas others lack them. In the sections studied, no nodule occurred within $600 \mu$ of the villus tip. Often more than one nodule occurs in a villus, some being even as far down as the base of a crypt but always on the lumen side of the muscularis mucosae. Thus the lymph nodules in the turkey duodenum are not comparable with mammalian Peyer's patches since the latter are distinctly submucosal in position. Throughout the propria, fibroblasts are found, accompanied by strands of white collagenous connective tissue. Elastic fibers (yellow elastic connective tissue) are not present in the tunica propria.

The propria of the turkey is heavily permeated with lymphocytes of various types. Clara (1925) found the tunica propria of all the birds he studied to be dense with them-heaviest in the chicken and duck and least so in the pigeon. Lymphocyte formation and multiplication occur throughout the tunica propria, though the greatest activity is naturally in the lymph nodules. "In der Regel," remarks Clara, "können wir aber sagen stellt die Tunica propria ein retikuläres, zytogenes Gewebe dar, in dem stellenweise die faserigen Elemente überweigen. ..."

The lymph nodules of the turkey are solitary, being equivalent to the secondary nodules of mammals. Within a nodule are reticular fibroblast cells, regularly distributed to form a suitable framework in which the nodular pulp cells may develop. The majority of cells within a nodule are lymphocytes of three distinguishable sizes : (1) Large lymphocytes (fig. 5 ; plate $7, C$ ) are sparsely scattered throughout. They average $10 \times 7.5 \mu$, and the nucleus has a diameter of $7 \mu$. The nucleus generally contains two nucleoli or a single bilobate one about $2.5 \mu$ in diameter. The cytoplasm is basophilic, with some granulation. (2) Medium-sized lymphocytes (figs. $5 ; 7 ; 8$; plates $7, C, D, E$ ) are chiefly present in the medulla and differ from the preceding in size. They average $5 \times 6 \mu$, and the nucleus has a diameter of $5 \mu$. The cytoplasm is the same as that of large lymphocytes. The medium-sized lymphocytes have usually a single nucleolus, occasionally two. (3) The small lymphocytes (figs. 3, 
$A ; 5 ; 8$; plates $5, D ; 7, C, E)$, most abundant in the cortical regions, vary considerably in size. The nucleus may be as small as $2 \mu$ in diameter, in which case it will stain darkly, or as large as $3.5 \mu$, when it is of a more typical wheel type. The latter, probably the younger form of the two, is presumably the ancestor of plasma cells and larger lymphocytes. The cytoplasm of small lymphocytes is also basophilic; it varies in amount, being sometimes so scant as to form only a slight border around the nucleus, and again it is abundant, in which event the nucleus is eccentric.

According to Jordan (1935) and Latta (1921), the various lymphoeytes are not distinct forms but different growth stages of the same cell.

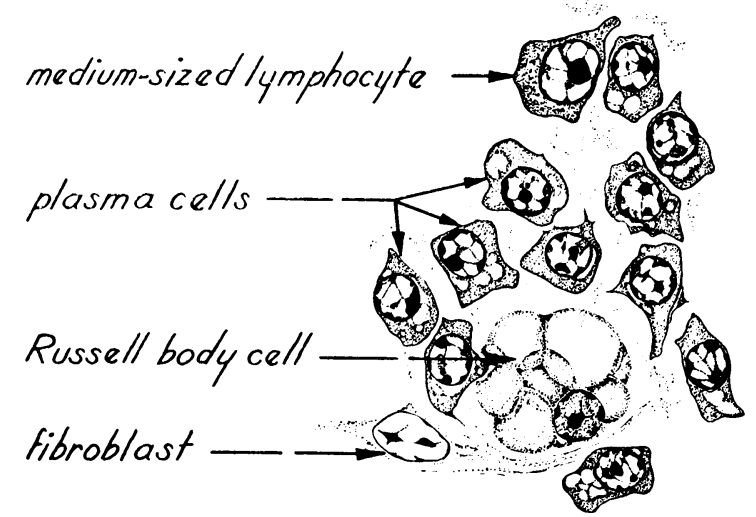

Fig. 7.-A portion of tunica propria from the lower part of a villus to show a Russell body cell and neighboring elements $\times 1280$ (compare plate $7, D$ ).

The large lymphocytes divide to form small ones, which in turn grow to medium size. In the turkey all three sizes of lymphocytes are also found in the tunica propria outside the nodule.

The most numerous cells of the tunica propria are the plasma cells (figs. $3, B ; 7$; plates $5, E ; 7, D$ ), generally conceded to be formed from small lymphocytes and incapable of further division. In structure, plasma cells resemble the young, small lymphocytes. They possess a typical wheel nucleus, with a well-defined central nucleolus, and the nucleus measures 3 to $4 \mu$. The cytoplasm is basophilic and possesses one to several vacuoles near the nucleus. The latter is generally eccentric in the cell body, which has a diameter of approximately $5 \mu$; but the cell shape varies from spherical to elongate.

Russell body cells (figs. 7; 8; plates $7, D, E$ ) are another type encountered in the propria of vertebrates. Thought to be formed most commonly from plasma cells, they have been reported as abundant only in pathological conditions. In the normal turkey, one finds them only ocea- 
sionally; they vary in size from the dimensions of a plasma cell up to $12 \mu$ in diameter, the latter thus being the largest cells occurring in the propria. Smaller ones may have a slightly eccentric, typical wheel nucleus. The cytoplasm is filled with numerous acidophilic globules, the Russell bodies. Large cells contain from two to many of these large acidophilic globules, and the nucleus may be pushed to the side of the cell and have its finer morphology obscured. Regarding the formation of Russell body cells, Maximow and Bloom (1938) state that when plasma cells degenerate, "large spherical drops or crystals of a peculiar acidophil substance frequently accumulate in the cell body. When the cytoplasm disintegrates, these inclusions are set free and remain between the other

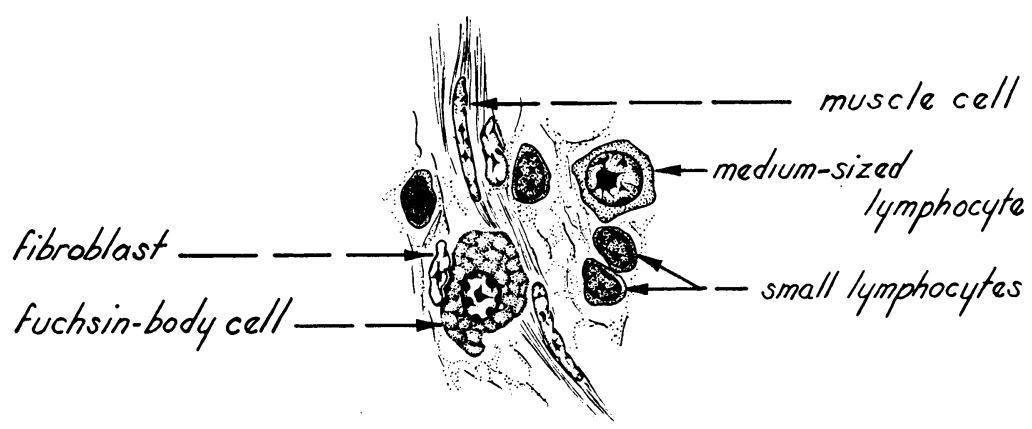

Fig. 8.-A leucocyte filled with fuchsin staining bodies, probably a young Russell body cell $\times 1280$ (compare plate $7, E$ ).

elements of the tissue as Russell bodies." Michels (1935), however, interprets these mulberrylike cells as erythrophages. He finds them abundantly in locations where erythrocytes have become extravasated and where plasma cells have made a heavy infiltration. In his opinion lymphocytes, monocytes, histiocytes, and endothelial cells, as well as plasma cells, may become erythrophages and hence are possible progenitors of Russell body cells. The variation in size of the Russell bodies is explained by assuming that the phagocytosed erythrocytes break into fragments, which then coalesce in varying degrees. Michels considers the Russell body cells an important aid to the hemoglobin-disintegrating reticuloendothelial system. In the turkey, however, their presence in scant numbers apparently precludes this interpretation.

The muscle fibers of the propria are typical smooth muscle cells, continuous with those of the muscularis mucosae.

Extravascular eosinophiles (fig. 3, $B$; plates $4, C ; 5, E ; 6, A, B$ ) are numerous at the base of the tunica propria, diminishing in abundance near the orifice of the crypts. Two types of eosinophiles are present--one with a polymorphic nucleus and crystalloid eosinophilic granules, the 
second usually with a nonlobate nucleus that may occasionally be polymorphic. The granules in this second type are larger than the crystalloids and are round. Both types of cells are found in the circulating blood of the turkey, the polymorphonuclear form occurring in the same relative abundance as the neutrophiles of mammals. A true neutrophile has not been observed in the turkey. Thus these two types of eosinophilic leucocytes of birds are comparable respectively with the neutrophiles and eosinophiles of mammals. Kasarinoff (1911) calls these forms "pseudo-eosinophiles" and "true eosinophiles." In the tunica propria the round granule type (true eosinophile) is far more numerous than the crystalloid form (pseudo-eosinophile).

In the turkey both types of eosinophiles are amphophilic after Susa's fixation; they stain lightly with eosin and intensely with hematoxylin. After Bouin's fixation the granular leucocytes of the propria are difficult to differentiate. After formalin fixation the granules have a fairly strong affinity for eosin but will retain hematoxylin unless carefully destained.

The hematoxylin staining gives the granules a true basophilic appearance which could easily lead one to misinterpret them as tissue mast cells. Jordan (1926), working with amphibia and teleosts, found basophilic cells to be numerous in the tunica propria, but was unable to consider them as mast cells. He believed them to be unripe, only partially ripe, or abortive degenerate eosinophiles. In the turkey they appear to be granular leucocytes that have migrated from the blood stream into the tunica propria. The pseudo-eosinophiles retain their round shape, and their crystalloid inclusions are morphologically identical with those of like cells in the blood stream. The true eosinophiles, however, do not remain round; their granules vary considerably in size but are always spherical. The reason for an altered staining affinity of eosinophiles located extravascularly in the propria is obscure.

The remaining portions of the duodenal wall are not complex in cellular detail and present no striking differences from mammalian tissues. The cells of all the muscle layers are identical in morphology and have the typical spindle shape of smooth muscle cells generally. Elastic fibers are present in all the various layers external to the tunica propria, being most abundant in the muscularis mucosae (plate $8, B$ ) and in the connective tissues on either side of it. The elastic fibers are usually oriented in the same direction as the muscle fibers among which they are found and are always accompanied by abundant collagenous connective tissue. The subserosa is composed of connective tissue, principally of the collagenous type, but contains also numerous elastic fibers, chiefly disposed in a longitudinal fashion, with some placed circularly. The serosa consists 
of a siugle layer of cells that forms a smooth covering for the viscera. The nuclei of the serosa cells are small and stain densely.

The enteric nerve plexuses, mentioned earlier in the paper, are histologically like those of mammals. The cells comprising the ganglia are generally seen in groups of four to eight in a 10- $\mu$ cross section of the intestine. They are large, measuring $14 \times 18 \mu$, with a nucleus of $12-\mu$ diameter. The nuclei are spherical with little chromatin; a single welldefined nucleolus occurs in each nucleus. In the cytoplasm, Nissl bodies are numerous. The ganglia are interconnected by nerve fibers.

\section{THE DUODENUM OF THE POULT}

The foregoing descriptions have been based on tissues from birds over eight months of age and here considered to be adults. A few observations have been made on younger birds-day-old and 5-months-old poultsand are recorded here for comparison with conditions obtaining in the older birds (see plate 1).

In a day-old poult the duodenal mucosa presents a regular picture of villus placement (plate, $1, A$ ). On first examination one sees definite double rows of rounded villi, set in alternating positions to form rows that run the length of the intestine. If the intestine is opened and flattened, a space appears between the double rows in which, on further examination, a comparable double row of shorter villi is revealed. Thus there are double zigzagged rows of large villi, with similar rows of shorter villi in between. As the bird becomes older, the shorter villi grow out, and by the time it reaches maturity one can distinguish no differences between any of the villi (plate $1, B, C$ ). The villi become more compressed and tonguelike as the bird matures.

In the poult the crypts of Lieberkühn are short, and the villi arise almost directly from the muscularis mucosae.

Lymph nodules do not occur in the tunica propria of the poult at hatching. At that time the propria is chiefly composed of fibroblasts, muscle fibers, and capillaries. A few lymphocytes are present. Some lymphocytic migration through villus epithelium occurs during the first day, and this becomes more common as the bird grows. By the end of two weeks lymphocytic aggregations are evident, and lymph nodules occur during the latter part of the first month of life. Eosinophiles are found in the propria, but not abundantly. Pseudo-eosinophiles do not occur early in the tunica propria. The muscularis mucosae and the longitudinal muscle layers are thin in the poult.

Goblet cells are numerous in the day-old turkey, but increase in relative numbers as the bird matures. This coincides with the finding (in Gallus gallus domesticus) of Ackert, Edgar, and Frick (1939), who be- 
lieve the increase in goblet cells to be a factor in age resistance to parasitism, at least for the nematode Ascaridia galli ${ }^{5}$ with which they were concerned.

${ }^{5}$ According to Beach and Freeborn (1936): "The name Ascaridia galli (Schrank, 1788 ) is accepted as the correct name for the European form of this worm, which was previously called $A$. perspicillum (Rudolphi, 1803). Ascaridia lineata (Schneider, 1866) was supposed to be the New World form. Recent comparisons of the two forms show no appreciable differences and hence the older name, galli, is used to include both forms." 


\section{LITERATURE CITED}

ACKerT, J. E., S. A. EdGAR, and L. P. Frick.

1939. Goblet cells and age resistance of animals to parasitism. Amer. Micros. Soc. Trans. 58:81-89.

BeACH, J. R., and S. B. FreEborn.

1936. Diseases and parasites of poultry in California. California Agr. Ext. Cir. 8:1-110. 5th ed.

Bizzozero, G.

1893. Ueber die schlauchförmigen Drüsen des magendarmkanals und die Beziehungen ihres Epithels zu dem Oberflächenepithel der Schleimhaut. Arch. f. Mikros. Anat. 42:136-37.

Cathoun, M. L.

1933. The microscopic anatomy of the digestive tract of Gallus domesticus. Iowa State Col. Jour. Sci. 7:261-382.

Ciaccio, C.

1907. Sopra speciali cellule granulose della mucosa intestinal. Arch. Ital. di Anat. e di Embriol. 6:482-98.

Clara, M.

1925. Beiträge zur Kenntnis des Vogeldarmes. I. Teil. Mikroskopische Anatomie. Ztschr. f. Mikros.-Anat. Forsch. 4:346-416.

1926a. Beiträge zur Kenntnis des Vogeldarmes. II. Teil. Die Hauptzellen des Darmepithels. Ztsehr. f. Mikros.-Anat. Forsch. 6:1-27.

1926b. Beiträge zur Kenntnis des Vogeldarmes. III. Teil. Die basalgekörnten Zellen im Darmepithel. Ztschr. f. Mikros.-Anat. Forsch. 6:28-54.

1926c. Beiträge zur Kenntnis des Vogeldarmes. IV. Teil. Über das Vorkommen von Körnerzellen vom Typus der Panethschen Zellen bei den Vögeln. Ztschr. f. Mikros.-Anat. Forsch. 6:55-75.

1926d. Beiträge zur Kenntnis des Vogeldarmes. V. Teil. Die Schleimbildung im Darmepithel mit besonderer Berücksichtigung der Becherzellenfrage. Ztschr. f. Mikros.-Anat. Forseh. 6:256-304.

1926e. Beiträge zur Kenntnis des Vogeldarmes. VI. Teil. Das lympho-retikuläre Gewebe im Darmrohre mit besonderer Berücksichtigung der leukozytären Zellen. Ztschr. f. Mikros.-Anat. Forsch. 6:305-50.

1927a. Beiträge zur Kenntnis des Vogeldarmes. VII. Teil. Die Lieberkühn'schen Krypten. Ztschr. f. Mikros.-Anat. Forsch. 8:22-72.

1927b. Beiträge zur Kenntnis des Vogeldarmes. VIII. Teil. Das Problem des Rumpfdarmschleimhautreliefs. Ztschr. f. Mikros.-Anat. Forsch. 9:1-48.

CORDIER, R.

1921. À propos des cellules argentaffines de l'intestin. Assoc. des Anat. [Paris] Compt. Rend. 16:61-68.

1923. Contribution à l'étude de la cellule de Ciaccio-Masson et de la cellule de Paneth. Soc. de Biol. [Paris] Compt. Rend. 88:1227-30.

JORDAN, H. E.

1926. On the nature of the basophilic granulocytes of the blood and the tissues. Anat. Rec. 33:89-106.

1935. The significance of the lymphoid nodule. Amer. Jour. Anat. 57:1-37. 
KASAKINOTF, D.

1911. Experimentelle Blutuntersuchungen bei Vögeln. Folia Haematologia 10: 391-413.

KAUPP, B. F.

1918. Anatomy of the domestic fowl. 373 p. W. B. Saunders Company, Philadelphia.

KeAsBey, L. E.

1923. On a new form of leucocyte (Schollenleukozyt, Weill) as found in the gastric mucosa of the sheep. Folia Haemotologia 29:155-71.

KULL, H.

1913. Die "basal gekörnten Zellen" des Dünndarmepithels. Arch. f. Mikros. Anat. 81:185-95.

1925. Die chromaffinen Zellen des Verdauungstraktes. Ztsehr. f. Mikros.-A nat. Forsch. 2:163-200.

Kultschitzkr, N.

1897. Zur Frage über den Bau des Darmkanals. Arch. f. Mikros. Anat. 49:7-35.

LATTA, J. S.

1921. The histogenesis of dense lymphatic tissue of the intestine (Lepus) : a contribution to the knowledge of the development of lymphatic tissue and blood-cell formation. Amer. Jour. Anat. 29:159-211.

MACKLIN, C. C., and M. T. MACKLIN.

1928. The intestinal epithelium. In: E. V. Cowdry. Special cytology. 2 vols., $x x$ +1348 p. Paul B. Hoeber, Inc., New York. (See specifically vol. 1, p. 171-85.)

Masson, $P$.

1914. La gland endocrine de l'intestin chez l'homme. [Paris] Acid. des Sci. Compt. Rend. 158:59-61.

1928. Carcinoids (argentaffin-cell tumors) and nerve hyperplasia of the appendicular mucosa. Amer. Jour. Path. 4:181-212.

Masson, P., and L. Berger.

1923. Sur un nouveau mode de sécrétion interne: la neurocrinie. [Paris] Acad. des Sci. Compt. Rend. 176:1748.

Maximow, A. A., and W. Bloom.

1938. A textbook of histology. $3 d$ ed. xiii +668 p. W. B. Saunders Company, Philadelphia.

Michels, N. A.

1935. Medullary and non-medullary erythropoiesis with special reference to the plasma-cell eyrthrophage or Russell body cell, and to the erythrocatheretic (erythrolytic) function of lymph nodes and hemal nodes. Amer. Jour. Anat. 57:439-501.

PARAT, M.

1924. Contribution à l'histophysiologie des organes digestifs de l'embryon. L'apparition corrélative de la cellule de Kultschitzky et de la secretine chez l'embryon. Soc. de Biol. [Paris] Compt. Rend. 90:1023-24.

ROSENBERG, L. E.

1940. Post-mortem autodigestion of the intestinal mucosa of the turkey. Stain Tech. 15:53-56. 


\section{SCHMIDT, J. E.}

1905. Beiträge zur normalen und pathologischen Histologie einiger Zellarten der Schleimhaut des menschlichen Darmkanales. Arch. f. Mikros. Anat. 66: $12-40$.

Simard, L. C., and E. V. Campenhaut.

1932. The embryonic development of argentaffin cells in the chick intestine. Anat. Rec. 53:141-60.

TANG, E. H.

1922. Ueber die Panethsehen Zellen sowie die gelben Zellen des Duodenums beim Schwein und den anderer Wirbeltieren. Arch. f. Mikros. Anat. 96:182-209.

WeILL, P.

1919. Ueber die leukocytaren Elemente der Darmschleimhaut der Säugtiere. $\Lambda \mathrm{r}$ reh. f. Mikros. Anat. 93:1-81. 

TABLE AND PLATES 
TABLE 1

Fixing, Staining, and Sectioning of Material Shown in Plates 1 to 8

\begin{tabular}{|c|c|c|c|c|}
\hline Plate no. & Age of hird & Fixative & Stain & $\begin{array}{c}\text { Thickness } \\
\text { of sec- } \\
\text { tions in } \\
\text { microns } \\
(\mu)\end{array}$ \\
\hline $1, A$ & 1 day & 10 per cent formol & None. & - \\
\hline $1, B$ & 5 months & 10 per cent formol & None.. & - \\
\hline $1, C$ & 1 year & 10 per cent formol & None...... & - \\
\hline 2, $A-D$ & 1 year & 10 per cent formol & Delafield's hematoxylin and eosin. & 10 \\
\hline 3, $A$ & 8 months & Susa's & Masson's trichrome............. & 10 \\
\hline $3, B$ & 8 months & Susa's & Heidenhain's hematoxylin and eosin.. & 7 \\
\hline 3, $C-D$ & 1 year & 10 per cent formol & Delafield's hematoxylin and eosin.... & 10 \\
\hline 3, $E$ & 1 month & Bouin's & Delafield's hematoxylin and eosin... & 10 \\
\hline 4, $A$ & 1 year & 10 per cent formol & Delafield's hematoxylin and eosin .. & 10 \\
\hline $4, B-C$ & 8 months & Susa's & Regaud's hematoxylin............ & 10 \\
\hline $4, D$ & 1 year & 10 per cent formol & Delafield's hematoxylin and eosin..... & 10 \\
\hline 5, $A$ & 8 months & Susa's & Regaud's hematoxylin and triosin.... & 7 \\
\hline $5, B-C$ & 8 months & Susa's & Regaud's hematoxylin.............. & 10 \\
\hline 5, $D$ & 1 month & Susa's & Regaud's hematoxylin.............. & 10 \\
\hline 5, $E$ & 8 months & Susa's & Regaud's hematoxylin and triosin..... & 7 \\
\hline $6, A, B$, and $D$ & 8 months & Susa's & Regaud's hematoxylin .............. & 10 \\
\hline $6, C$ & 8 months & Susa's & Masson's trichrome........... & 10 \\
\hline 7, $A$ & 8 months & Susa's & Regaud's hematoxylin.... & 10 \\
\hline $7, B$ & 8 months & Susa's & Regaud's hematoxylin and triosin... & 7 \\
\hline 7, $C$ & 1 year & 10 per cent formol & Delafield's hematoxylin and eosin... & 10 \\
\hline $7, D$ & 8 months & Susa's & Heidenhain's hematoxylin and eosin.. & 7 \\
\hline 7, $E$ & 8 months & Susa's & Masson's trichrome................. & 10 \\
\hline 8, $A$ & 5 months & 95 per cent alcohol & Delafield's hematoxylin and eosin.... & 10 \\
\hline $8, B$ & 8 months & Bouin's & $\begin{array}{l}\text { Delafield's hematoxylin light green and } \\
\text { orcein } \ldots \ldots \ldots \ldots \ldots \ldots \ldots \ldots \ldots \ldots \ldots\end{array}$ & 10 \\
\hline 8, $C-D$ & 1 year & 10 per cent formol & Delafield's hematoxylin and eosin . . . . . . . & 10 \\
\hline
\end{tabular}



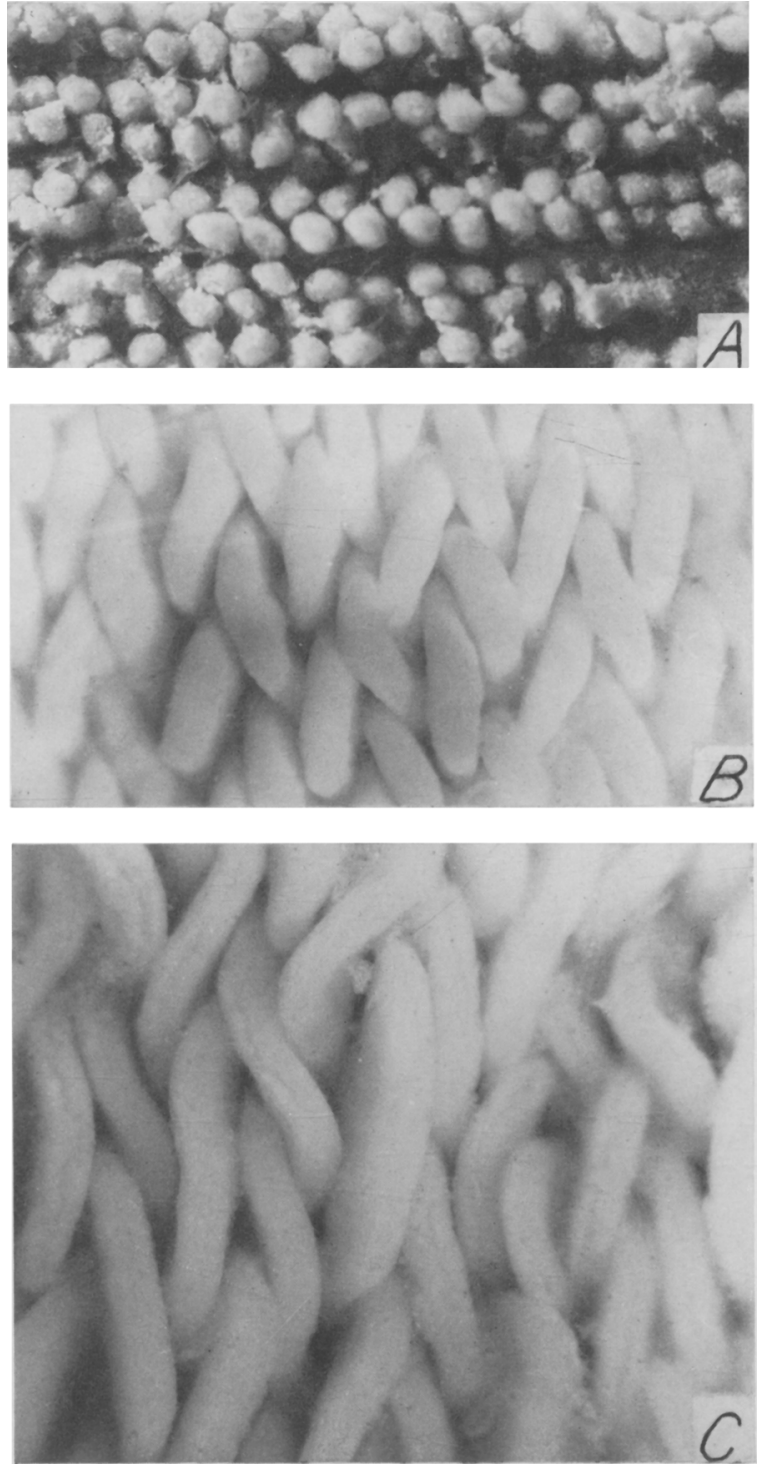

Plate 1.--Surface views of the duodenum $(X 26)$ pinned open and immersed in formalin (photographs taken through the aqueous medium): $A$, tissue from a day-old turkey; $B$, from a five-months-old turkey; $C$, from a year-old turkey. 

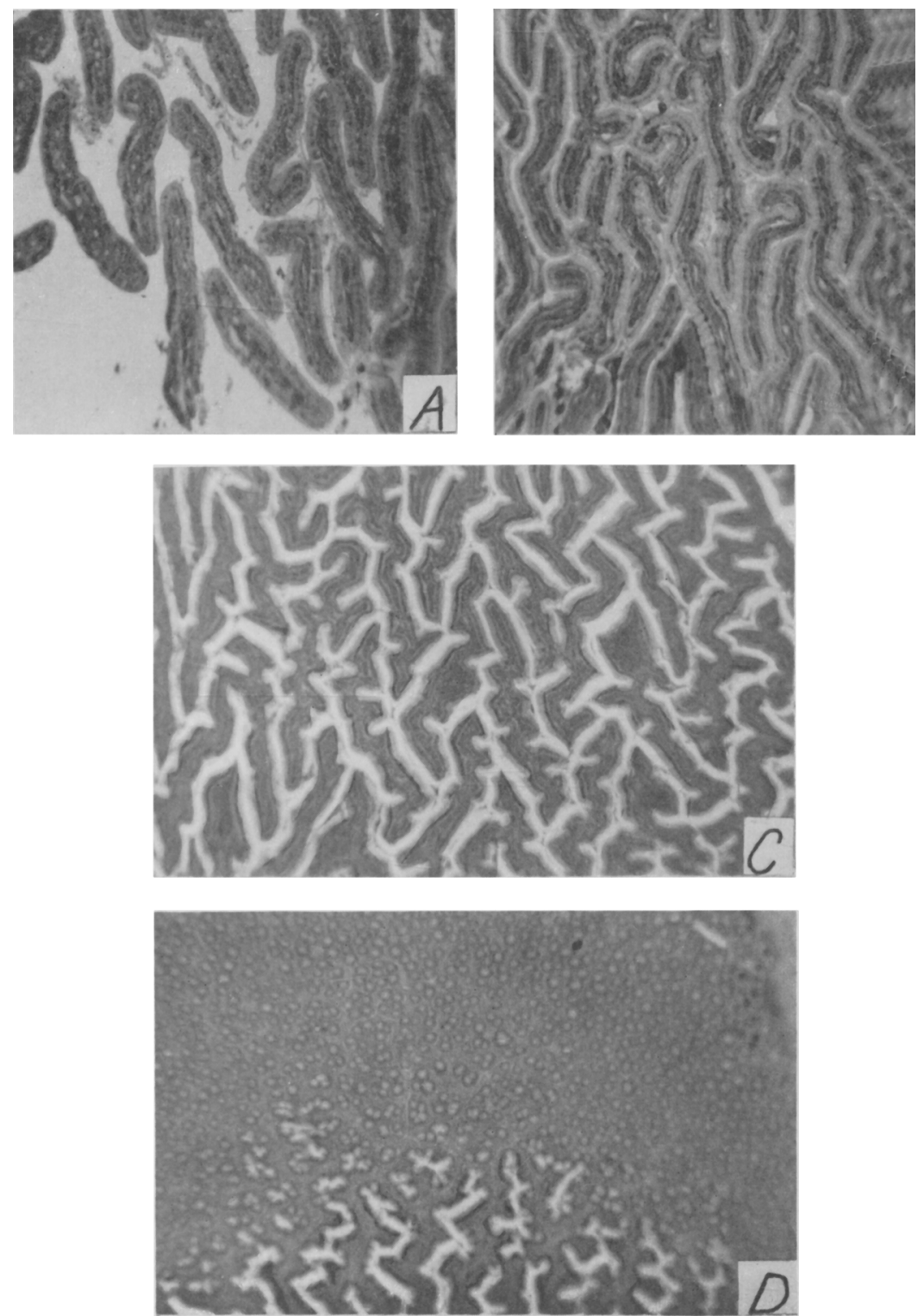

Plate 2.- Surface sections $(X 26)$ of a small area of duodenum of an adult turkey to show the change in contour of the villi from their tips, $A$, to the crypts of Lieberkühn, $D$. 

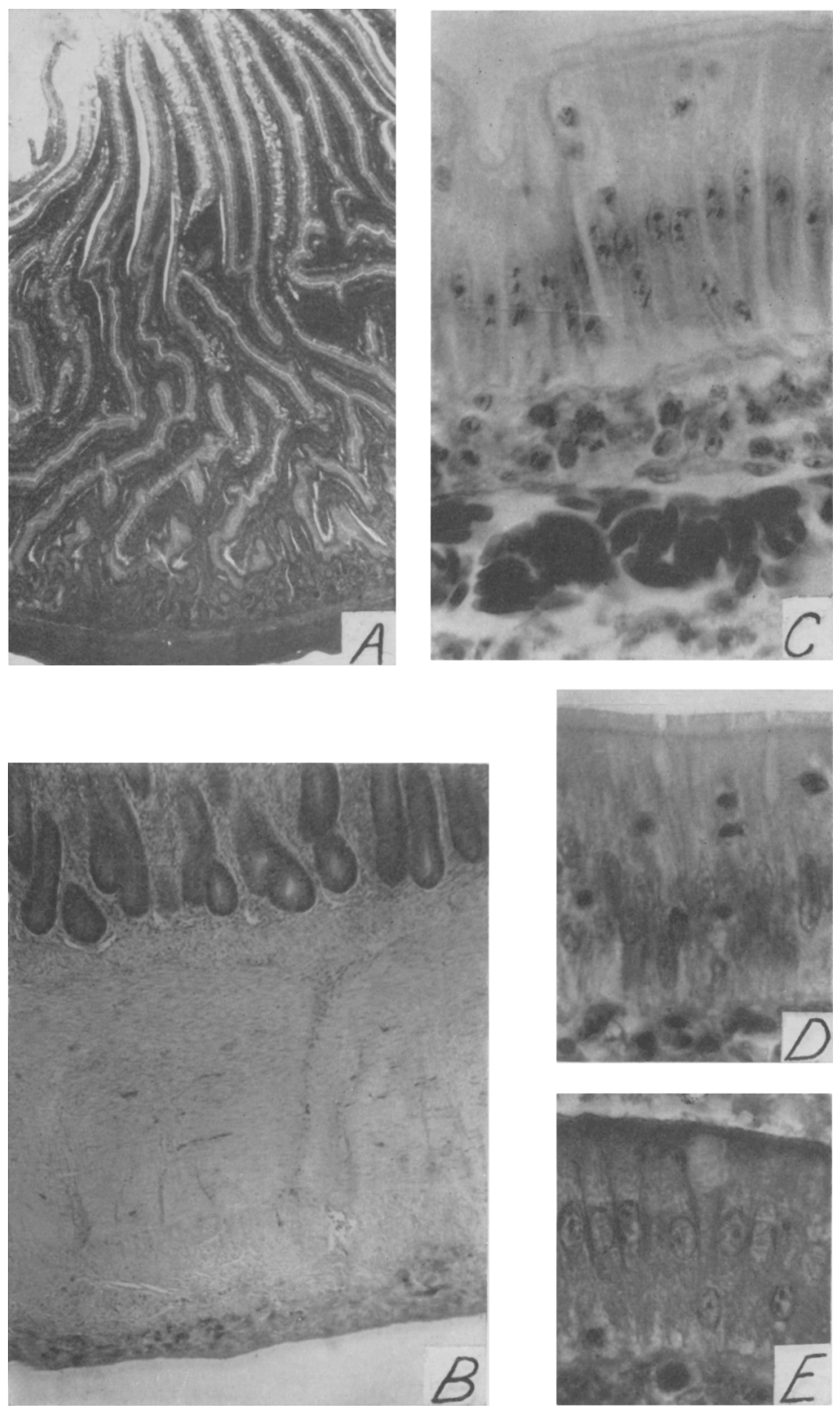

Plate 3.-A, Cross section $(\times 26)$ of duodenum of adult turkey illustrating the relative lengths of villi and the crypts of Lieberkühn (note the relatively thin muscular portion of the wall); $B$, the muscular wall $(X 67) ; C$, a portion of a villus cut longitudinally in which a blood capillary is shown separated by only a few cells from the membrana propria: $D$, chief cells and young goblet (mucous) cells of the villus epithelium; $E$, mature goblet cell of villus epithelium $(C, D$, and $E \times 640)$. 

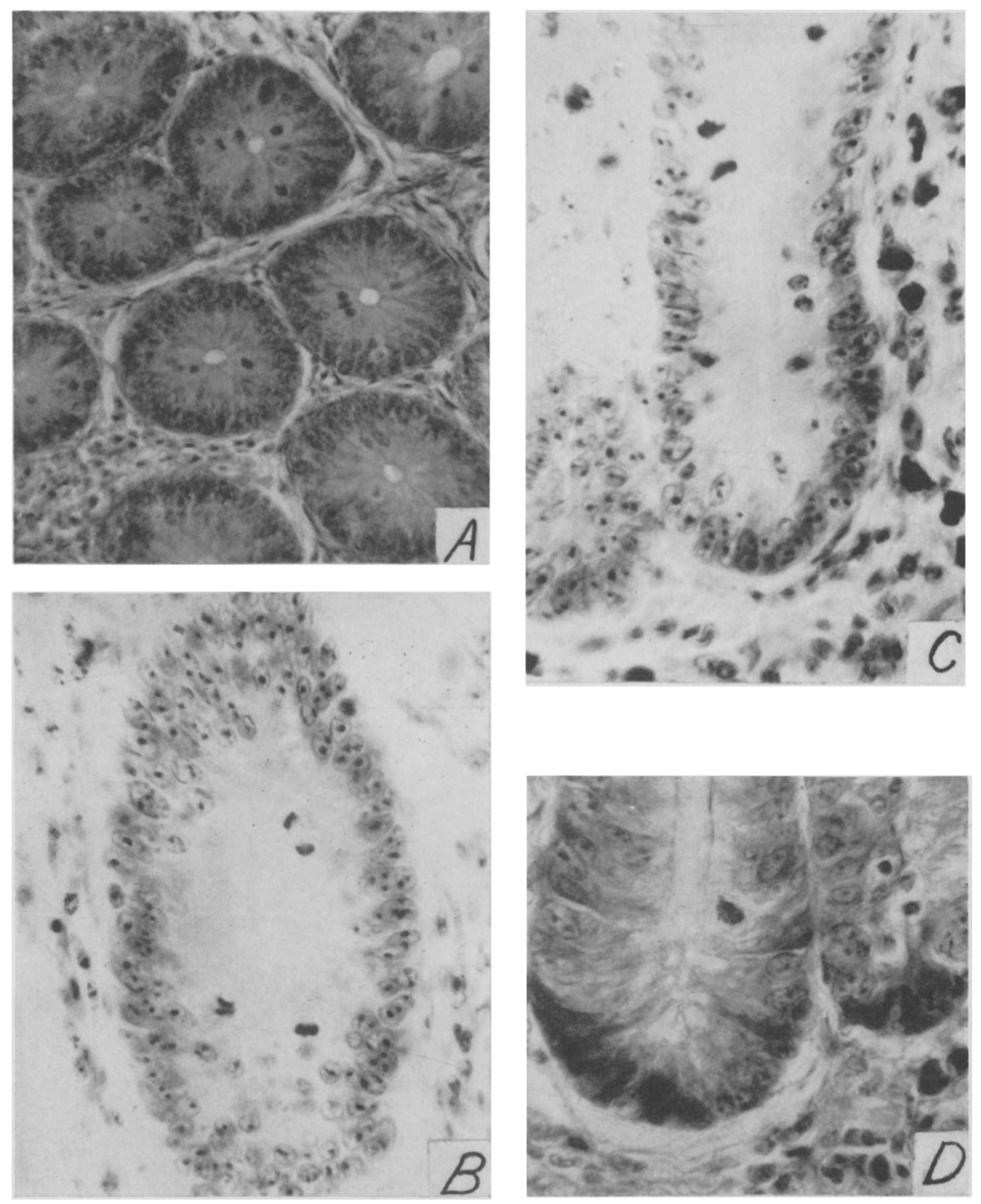

Plate 4.-A, Crypts of Lieberkühn in cross section, showing the abundant mitoses therein ( $\times 300) ; B, C$, and $D$, crypts in longitudinal section with mitotic figures of various stages $(\times 640)$. 

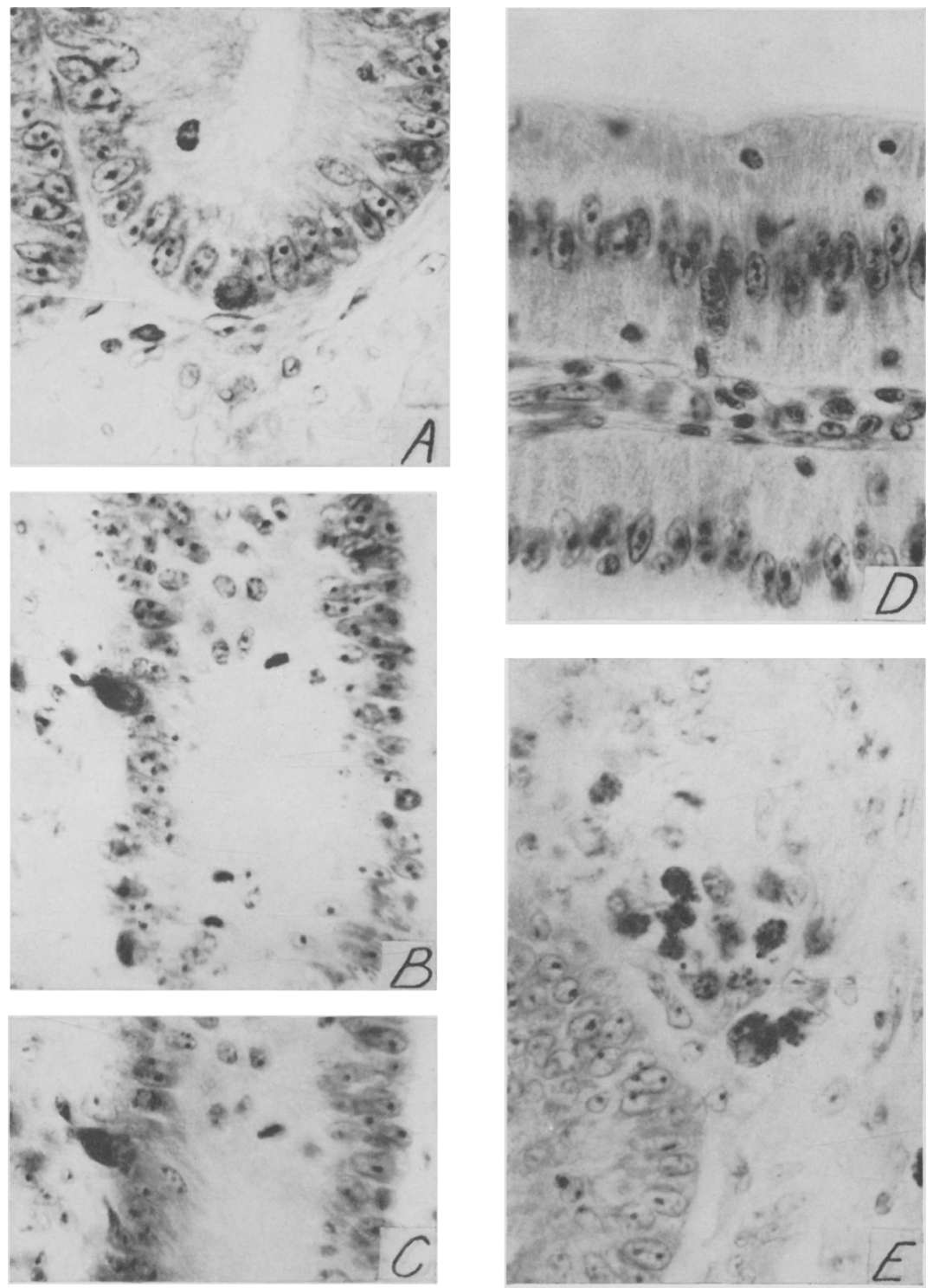

Plate 5.-Basal granular cells $(\times 640): A$, basal part of a crypt in longitudinal section (compare text fig. $4, B$ ). $B$ and $C$, Middle portion of a crypt with migrating lymphocyte penetrating the membrana propria at the base of a basal granular cell (compare text fig. 4, $A$ ). $D$, Villus epithelium in longitudinal section with a similar phenomenon (compare text fig. $3, A$ ). $E$, Basal granular cell free in the tunica propria (compare text fig. $3, B$ ). 

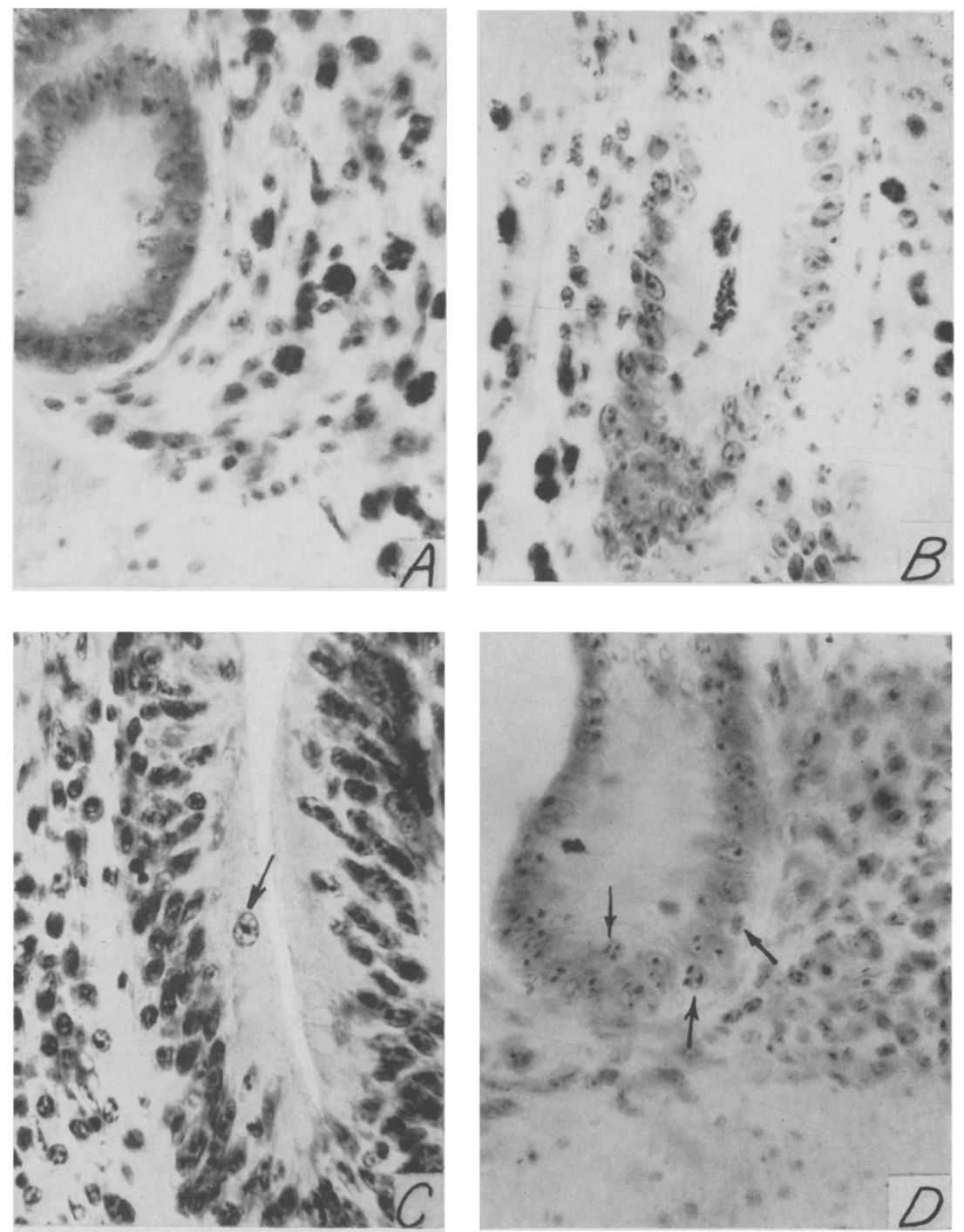

Plate 6.-Longitudinal sections of the crypt region $(\times 640): A$, free eosinophiles in the tunica propria; $B$, a section similar to $A$, but two eosinophiles have migrated into the lumen of the crypt; $C$, a large lymphocyte migrating through the crypt epithelium; $D$, schollenleucocytes in the crypt epithelium (compare text fig. 6 ). 

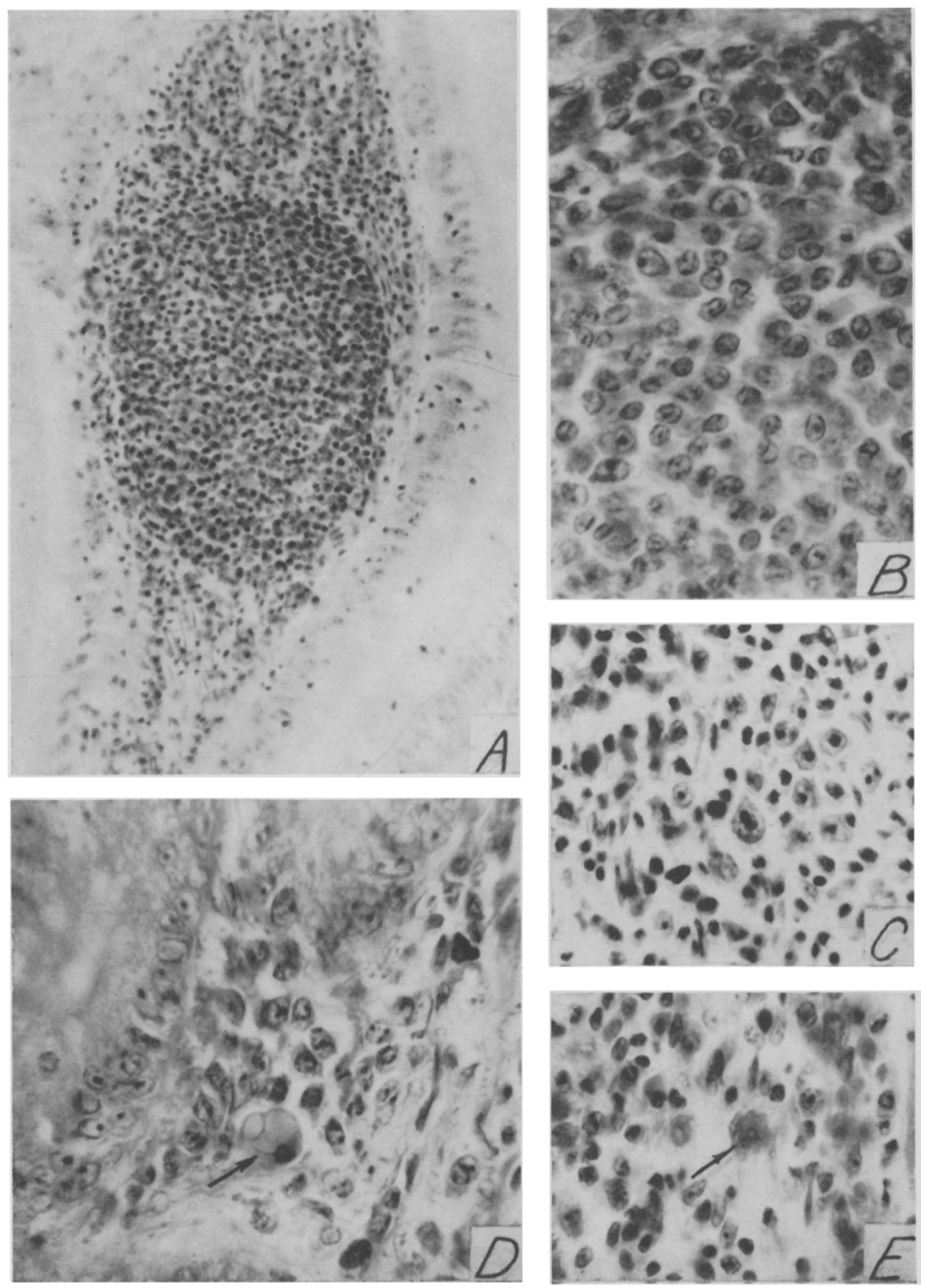

Plate 7.-A, Lymph nodule of a villus cut longitudinally $(\times 300) ; B$, the same $(\times 640)$. $C$, Lymphocytes of the tunica propria $(\times 640)$ from the middle portion of a villus (compare text fig. 5). $D$, Russell body cell and neighboring elements $(X 640)$ in the tunica propria of the crypt region (compare text fig. 7 ). $E$, A cell filled with granules $(\times 640)$ which stain with fuchsin, probably a young Russell body cell (compare text fig. 8 ). 

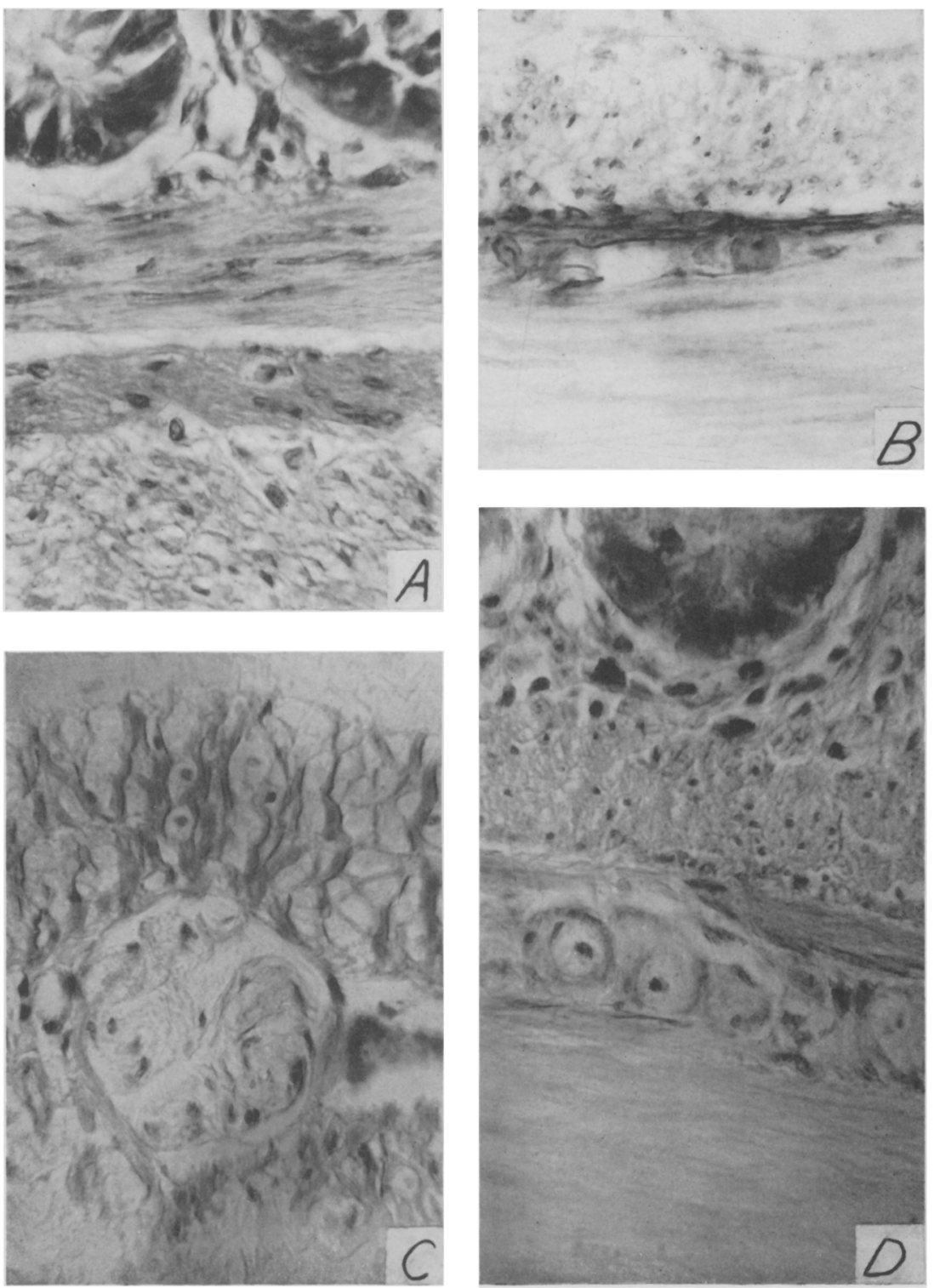

Plate 8.-A, A longitudinal section of duodenum showing the accessory layer of circular muscle between the muscularis mucosae and the circular muscle of the muscularis. $B$, A cross section of duodenum showing the distribution of elastic fibers in the connective tissue between muscularis mucosae and the accessory circular muscle. $C$, A cross section of nerve of Auerbach's plexus located in the longitudinal muscle of the muscularis. $D$, Ganglion cells of Meissner's plexus as seen in a cross section of the duodenum. (All figures $\dot{X} 640$ ). 